\title{
ARTÍCULO
}

\section{El constitucionalismo democrático y social: orígenes y características distintivas}

\section{Democratic-social constitutionalism: origins and distinctive features}

\author{
Mattia Gambilonghi \\ Universidad de Génova, Universidad Libre de Bruselas
}

Fecha de recepción 28/05/2020 | De aceptación: 13/10/2020 | De publicación: 28/12/2020

\section{RESUMEN.}

El artículo tiene por objeto reconstruir la evolución doctrinal del pensamiento jurídico en la transición del constitucionalismo liberal - identificable con las teorías del "Estado de derecho" del siglo XIX - al constitucionalismo democrático-social que inspira y configura el "Estado social". En resumen, el constitucionalismo democrático-social puede considerarse el núcleo fundamental del pacto social mediante el cual la civilización europea y occidental logra ofrecer una alternativa democrática a la desintegración de los Estados liberales. Los principales rasgos del nuevo constitucionalismo se analizarán centrándose en lo que, en nuestra opinión, puede considerarse sus principales "pilares".

\section{PALABRAS CLAVE.}

Estado social, constitucionalismo, democracia de masas, Mortati, igualdad sustancial.

\section{ABSTRACT.}

The paper aims to reconstruct the doctrinal evolution of the juridical thought in the transition from liberal constitutionalism - identifiable with the nineteenth-century theories of the "rule of law" - to democratic-social constitutionalism that inspires and shapes the "Welfare State". In short, democratic-social constitutionalism can be viewed as the fundamental core of the social pact through which the European and Western civilisation manages to provide a democratic alternative to the disintegration of the liberal states. The main features of the new constitutionalism will be analyzed by focusing on what, in our opinion, can be considered its main "pillars".

\section{KEY WORDS.}

Welfare State, constitutionalism, mass democracy, Mortati, substantial equality. 
Sumario: 1. Introduction. 2. From the "individual" to the "person": a new anthropology for a new constitutionalism. 3. In search of a new foundation: material constitution and normativisation of fundamental political principles. 4. Democratic constitutionalism and property: between relativisation and functionalisation. 5. New constitutionalism and substantial equality: what type of relationship? 6. The labour's role in the democratic constitutionalism: between social subject, fundamental right and juridical science. 7. "Labour principle" and forms of sovereignty in the democratic constitutions: an excursus on the Italian case. Bibliography.

\section{Introduction}

What in a recent conference was defined as the "Weimar moment"1 had the main effect of outlining an innovative and alternative form of State with respect to the paradigm of the nineteenthcentury liberal State of law, the form of State within mass democracies developed until the end of the 1970s. That is, until the beginning of the neoliberal cycle, that progressively deconstructed the pillars on which the building of the Welfare State rested by radically modifying its material constitution (because of the direct interventions on the formal constitutions of post-war democracies that had a minimal and marginal character).

The term "Welfare State" has to be used to provide a more precise definition of this phenomenon and to indicate the political forms and constitutional models that emerged from "social pacts" which innovated the material constitutions of European and Western States following the significant transformations that took place in the 1930s. These transformations operated fundamentally in two ways. On one hand, by redrawing the borders and existing relations between the State and market, between the political and social, that is, making this a moment of the State through the well-known "Keynesian equation"; namely, the regulation of the propensity to consume thanks to an additional demand supplied and introduced by the public authorities - which are the main factor of the economic cycle, with fundamental functions both in the mechanism of accumulation, considering themselves as a Stateentrepreneur, and in the circulation and redistribution through the fiscal instrument and the management of public expenditure ${ }^{2}$. On the other hand, because the State becomes a market subject bearer of a non-

1 "Weimar Moments. Constitutionalising mass Democracy in Germany, Italy, Spain and beyond", Madrid, 13-15 November 2019.

2 RAPINI, A., Lo Stato sociale, Archetipolibri, Bologna, 2010; CONTI, F., SILEI, G., Breve storia dello Stato sociale, Carocci, Roma 2013. 
commercial $\operatorname{logic} c^{3}$, by carrying out a profound transformation of the mechanisms of representation, mediation and formulation of decisions ${ }^{4}$. Through these ones, it intends to react to the inadmissibility of traditional mediations (based on the self-regulated market and "exchange of equivalents" ${ }^{5}$ ) and atomistic conception of the representation in the liberal scheme (based on the pre-eminence of the figure of the citizen-owner within the social organization ${ }^{6}$ ). The primacy held by mass parties (on the institutional side) and trade unions (on the social side), as the main means of mediation of social needs and demands, in the management of political exchange; the redefinition of this mechanism of exchange in a triangular sense; its positioning within the state framework typical of pluralist democracy, aimed at producing a permanent dialectic between social groups": these are the fundamental characteristics of the "corporatist refounding" of political representation in Western societies during the "glorious thirty"8. Thus, the Welfare State is a political-constitutional organization model of the capitalist society which is not understandable in purely political or economic terms, and in which politics and economy cease to be autonomous and rigidly separated spheres, to become, on the contrary, contiguous and subject to processes of mutual interpenetration.

Since the different Welfare States produce and are characterized by an autonomous constitutional elaboration, this study is aimed at reconstructing the evolution of the juridical thought in the transition from liberal constitutionalism - identifiable with the 19th century theories of the "rule of law" - to the democratic-social constitutionalism that inspired and substantiated Welfare States. A constitutionalism, that, recalling the famous Mortatian categorization ${ }^{9}$, on the formal level finds its consecration in the drafting and promulgation of the Weimaran Constitution and postwar constitutions, on the material level its fundamental principles are also rooted in other political systems. These systems, which perhaps do

3 BARCELLONA P., CANTARO, A., La sinistra e lo Stato sociale, Editori Riuniti, Roma 1984.

4 DE FELICE, F., La storiografia delle élites nel secondo dopoguerra, in Italia contemporanea, 1983, n. 153.

5 BARCELLONA, P., Stato e mercato, De Donato, Bari 1976.

6 DE FELICE, F., "I tre volti del fascismo maturo", en MARRAMAO, G., TRONTI, M., VILLARI, L., DE FELICE, F., (eds) Stato e capitalismo negli anni Trenta, Editori riuniti, Roma, 1979.

7 RITTER G., Storia dello Stato sociale, Laterza, Bari, 1996; DE FELICE, F., "La formazione del regime repubblicano", En GRAZIANO, L., TARROW, S., (eds) La crisi italiana, Einaudi, Torino, 1976; MARRAMAO G., Dopo il Leviatano. Individuo e comunità, Bollati boringhieri, Torino, 1995.

8 MAIER, C. S., La rifondazione dell'Europa borghese, Il Mulino, Bologna, 1999; D’ALBERGO, S., "Dalla democrazia sociale alla democrazia costituzionale", Costituzionalismo.it, 3/2005.

9 MORTATI, C., “Costituzione, dottrina generale”, en Enciclopedia del diritto, XI, Giuffrè, Milano, 1962. 
not concern any innovations or constitutional ruptures from the formal point of view, but which, on the material level, live through the transformations of the State apparatus and forms of regulation of social conflict that are very similar to the ones of countries that adopt new constitutions. For instance, Sweden began to build a modern Welfare State in the 1930s, but it formalised these orientations from a constitutional point of view during the constitutional reform of the Regeringsform in $1976^{10}$.

Democratic-social constitutionalism is certainly the theoretical-constitutional framework of the Welfare State regimes, but it cannot be relegated to the level of pure doctrine. Rather, it must be considered, on the material level, as the set of principles and guidelines that emerged from the crisis of the $1930 \mathrm{~s}^{11}$. The fundamental nucleus, in short, of the social pact through which European and Western civilization managed to provide a democratic alternative to the disintegration of Liberal States (from which - except in very rare cases - the different European fascisms with their authoritarian, totalitarian and organicistic recipes had initially benefited $)^{12}$.

To trace the main characteristics of this new constitutionalism, the attention should be focused on what can be considered its main pillars.

\section{From the "individual" to the "person": a new anthropology for a new constitutionalism}

The first element to be addressed, in order to understand the specificity of the innovative charge of democratic-social constitutionalism, is the adoption of the interdependent and interconnected "person" (instead of the selfish and atomized individual) as an anthropological reference of the new politicalconstitutional models. This concerns the redefinition of the conception of the individual, anthropology that permeates it and the structure, and type of relationship that exists between the individual and the rest of society ${ }^{13}$. In fact, by redefining this conception and this link between the individual and society, the modern category of "social rights" takes shape. This represents one of the most characteristic elements

10 SCHEININ, M., (eds), Welfare state and constitutionalism: nordic perspectives, Nordic Council of Ministers, Copenaghen, 2001.

11 For these features, see also: RUIPEREZ, A, El constitucionalismo democrático en los tiempos de la globalización: reflexiones rousseaunianas en defensa del estado constitucional democrático y social, Universidad Nacional Autónoma de México, México D. F., 2005.

12 For a different point of view, FORSTHOFF, E., Rechtsstaat im Wandel : Verfassungsrechtliche Abhandlungen 1950-1964, W. Kohlhammer, Stuttgart, 1964.

13 COSTA, P., “Alle origini dei diritti sociali: «Arbeitender Staat e tradizione solidaristica»”, en GOZZI, G., (eds.), Democrazia, diritti, costituzione: i fondamenti costituzionali delle democrazie contemporanee, Il Mulino, Bologna, 1997. 
of the "constitutionalism of the second wave". The philosophical anthropology at the basis of the atomistic conception of the irrational and selfish individual-monad is contested and questioned because of its abstract and metaphysical nature. The need that several nineteenth-century thinkers have in common was to correct this conception by emphasizing and highlighting not so much the autonomy of the individual, but the set of links, bonds or "debts" that bind the former to the latter. The aim of this reflection is the development and theoretical definition of the so-called "social man"14.

The intellectual itinerary that led to this figure was long and jagged. Its origins can be identified in the famous Marxian criticism of the figure of the citoyen made in the Jewish Question, where Marx questioned the agonistic conception of the individual - an individual who sees in the other either a danger or a factor limiting his freedom. Then, its definition continued through a plurality of thinkers: this is the case of Lorenz von Stein, who, deeply influenced by Hegelism, considers the State as the "field of realization" of the individual personality. A State seen, on the basis of Hegel's, as the universal realized and as "the principal means of the individual's commitment to collective interests"15. Going beyond the nucleus of Natural Law and Lockean anthropology - the subject-of-needs - von Stein recognizes that, in order to realize what he defines as an "expansive personality" ${ }^{16}$, the individual needs to take note of the multiplicative potentiality in the relationships he maintains with other individuals and, in that community which constitutes the original cell of the State.

Afterwards, France was be the main theatre of the theoretical development of the figure of the social man. The latter fact is demonstrated by Émile Durkheim ${ }^{17}$ standpoint which, starting from the high interdependence that would characterise industrial societies and the division of labour within them, claims that the forms of regulation through which to combat the anomie and individualistic degeneration produced by liberalism, and through which to impose a new "organic solidarity". On the basis of the reflections of Espinal and his attempt to translate the organicistic scheme from natural sciences to social sciences, exponents of French Solidarist Mouvement, such as Alfred Fouillé and Lèon Bourgeois, A. (eds), Progettare l'uguaglianza. Momenti e percorsi della democrazia sociale, Mimesis, 2019 
defined the concepts of social debt and mutual obligation, using the idea of solidarity both as an analytical tool and as a normative principle. Through the "lens" of solidarity, the individual becomes something "secondary" and "derived from the social relations of which he is a part"18, which define precisely its most intimate essence. The conditions and fortunes of each individual represent, on the contrary, the result of the interaction (even fortuitously) of external factors and can be rebalanced starting from the recognition of each person's debts and credits towards the society.

Solidarist reflection, however, emerges from a purely philosophical dimension and is translated in terms within legal science and its debate thanks to Léon Duguit, one of the main French exponents of legal anti-formalism. By challenging the juridical category of subjective law - that represents the transposition of 18th century legal anthropology into the Codes - Duguit questioned the very idea of a naturalistic and pre-social foundation of rights. According to him, the law belongs to the subject because of it is a member of society, assuming the role of a social function. The only right that really exists is the objective one, which is an expression of society - and not of the State, (another element that distinguishes Duguit from the legal positivism of Jellinek and Carré de Malberg). This objective right creates "situations of advantage and disadvantage, of claims and obligations"19 for individuals, rather than rights,

Duguit's anti-subjectivist battle is relevant because, by extending the logic of his initial reasoning to the field of public law, it contributed to elaborate a theory about the positive claims of society towards the State, which constitutes, in nuce, an initial formulation of modern and twentieth-century social rights. Duguit established the pre-eminence of society over the State, especially about the production process of law, the règle $d u$ droit, claiming that "law" emerges "from the very structure of society"20. Thus, Duguit firmly rejected the Jellinekian theory of the State-person (which he saw as a simple transposition into public law of that subjectivism already criticized in the field of private law) and individual rights as self-limitations of the former. The State is not, for Duguit, a collective subject endowed with personality and an absolute sovereignty called to self-limit itself, but represents "a series of political relations, of

18 COSTA, P., “Alle origini dei diritti sociali”, cit., p. 311.

19 Ivi, p 328.

20 Ivi, p. 329.

CEFD Número 43 (2020) I ISSN: 1138-9877 | https://doi.org/10.7203/CEFD.43.17793 
relations of dominance", "a set of subjects concretely acting against other subjects" 21 . It is by virtue of this relational nature of the State and its subordination to society and social law that it is possible to obtain not only a more effective safeguarding of the system of individual rights and freedoms, but also a clear qualitative change in this system. The latter goes from being purely negative and guaranteeing to being positive and oriented towards the satisfaction of specific needs (work, education, subsistence, etc.). According to a circular scheme, the State finds in society both its presupposition, as a mere expression of the dynamics and power relations in force within it, and its "ultimate goal"22, since its action is oriented towards strengthening its internal cohesion. The State conceived as a "referee" and "night watchman", typical of liberal constitutionalism, became a State conceived as an "organiser of public services"23 aimed at the development of the individual and his personality, emerged. This is a set of ideas that crossed the French intellectual debate subterraneously and re-emerged during the drafting of the constitutional projects for the IV French Republic, where the social rights were defined in the Preamble. Furthermore, this set of ideas was inside the commentary of Vedel and Rivero as droits-créances, namely the rightscredits that impose on society and the State positive performances towards the individual ${ }^{24}$.

Through the gradual and progressive sedimentation of these reflections, it emerged a passage from the liberal idea of the individual to the one which, according to socialist constituent Lelio Basso, represented the new gravitational centre of post-war social democracies: the concept of the person ${ }^{25}$. The category of "person" conceives "man not in an abstract form of subjectivity but in the concreteness of his existence"26. A person, unlike the individual-monad of liberalism, is defined and expressed not only in the economic-market dimension, but through a multiplicity of dimensions and relationships. Society is not a limit or something to protect from, it is not - according to Kant - a "necessary evil", but the place

21 Ivi, p. 327.

22 Ivi, p. 332.

23 Ivi, p. 331.

24 RIVERO, J., VEDEL, G., "Les principes économiques et sociaux de la Constitution: le préambule”, Droit social, n. 31, 1947; GUERRIERI S., "I giuristi e la genesi dello Stato sociale in Francia: dalla Liberazione alla Costituzione del 1946", Quaderni fiorentini per la storia del pensiero giuridico, n. 46, tomo I, 2017, pp. 490-491. For an overview of the Latin American case, see also: MARQUARDT, LLINAS, PEREZ (eds.), Querétaro 1917 \& Weimar 1919: el centenario del constitucionalismo de la democracia social, Grupo Editorial Ibáñez, Bogotá, 2019.

25 BASSO, L., Il principe senza scettro. Democrazia e sovranità popolare nella Costituzione e nella realtà italiana, Feltrinelli, Milano, 1958.

26 SINZHEIMER, H., "La democratizzazione del rapporto di lavoro", en VARDARO, G., ARRIGO, G.(eds), Laboratorio Weimar. Conflitti e diritto del lavoro nella Germania prenazista, Edizioni Lavoro, Roma, 1982, p.66. 
in which "one's personality unfolds entirely", and this thanks to those "infinite social relationships" that certainly condition, for better or for worse, its existence, and at the same time "enrich it"27. This is a conception that, while rejecting the subjection and annihilation of organicism and pre-liberal corporatism, succeeds in enhancing "the moment of sociality" - coessential for Basso to the one of "individuality"28 - and defining a new type of freedom, the freedom-participation, which achieves a dialectical balance between these two poles.

\section{In search of a new foundation: material constitution and normativisation of fundamental political principles}

Another important element of mutation within constitutional theory was the new way of conceiving the foundation and objective order on which Statehood and the "formal constitution" should rest. This is an intellectual process that, finally, led to Costantino Mortati's formulation about the theoretical category of material constitution. The latter can be understood as an alternative response to the formalistic solution provided by Kelsen through his normativism, and to the progressive and inevitable disappearance of that "compact, homogeneous and well-ordered people" assumed by Savigny and Jellinek as the foundation and presupposition of the stability of the State construction. In fact, Kelsen's theoretical solution questioned the very plausibility of this monolithic and harmonic vision of the "people", by emphasizing the pluralistic nature of a society increasingly articulated and irreducible to any unitary principle. The State, according to Kelsen, must take as its originator an element of "formal" character, that is, the mediating and compromising will expressed by all the political and social forces, the will to give itself a fundamental law aimed at establishing the main rules of political coexistence ${ }^{29}$. In previous doctrines the legal order of a "historically founded community" - and the correspondence of the political form to it - represented the element of stabilisation and stability of State institutions. In that moment, in Kelsen's opinion, the Grundnorm, the formal and written constitution - and therefore "the rules of procedure established in order to determine a peaceful settlement of the interests at stake" 30 represented that stabilisation. In modern massified and pluralist societies, the social and political order

27 BASSO, L., Il principe senza scettro, cit., p. 39.

28 Ibid.

29 FIORAVANTI, M., "La crisi dello Stato liberale di diritto", Ars interpretandi. 2011,n. 1, pp. 87-90.

30 Ivi, p. 90.

CEFD Número 43 (2020) I ISSN: 1138-9877 | https://doi.org/10.7203/CEFD.43.17793 
was no longer something to be taken for granted, to be respected and preserved, but became an "objective to be pursued" 31 .

Among the theoretical positions that arose in response to Kelsen's formalism, the best known is the one conducted by Carl Schmitt in the name of a conception of the constitution that - proposing in a "polemical" key the basis of old Savignyian theories and bending them in an eminently political sense is anchored to an objective order, to assume the reference to constituent power and fundamental decisions as central and qualifying. According to Schmitt, the constituent power and decision-making function implied, however, the search for a mythical "unity of the people", the only one which can allow the latter to clearly express their will. Hence, a monocratic figure like the President of the Republic (of Weimar), who, unlike a powerless Parliament, would be capable of representing and maintaining that unity of the will of the sovereign people, otherwise dispersed in a thousand rivulets ${ }^{32}$. It is evident how Schmitt's emphasis on the indispensable homogeneity of the sovereign people makes its political theory incompatible and inassimilable to modern democratic-social constitutionalism, by coming into conflict with the increasingly pluralistic nature that representative democracy was progressively assuming not only from a political but also from a social point of view.

On one hand, constitutional and mass democracies were indebted to Kelsen's doctrine with regard to the idea of the primacy of the Constitution in the hierarchy of sources and the consequent jurisdictional control of constitutionality over the norms. On the other hand, however, while rejecting Schmitt's solution, they were not able to assume as the foundation of their legitimacy a purely technical and procedural element, as Kelsen's thought would like. The work of Costantino Mortati faces the dilemma that opposes the pluralism of Kelsen's "formal constitution" to the monism and homogeneity of Schmitt's "material constitution", mediating between these two perspectives. Without prejudice, in fact, the substantiality of a foundation that is not purely formal-procedural is identified by Mortati not in a people conceived harmonically as homogeneous and monolithic, but rather in the set of principles, values, strategic choices and fundamental guidelines placed at the basis of a constitutional text. These fundamental and inalienable orientations form the material constitution of a political system. Orientations

31 FIORAVANTI, M., "Le dottrine della costituzione in senso materiale”, Historia constitucional, 2011, n. 12, p. 25.

32 FIORAVANTI, M., Costituzione, Il Mulino, Bologna, 1999, pp. 148-150. 
are established and defined by the constituent power, namely the set of social and political forces that in a given historical moment manage to create an agreement and a great compromise around the guidelines and the "long-term options"33.

Mortati's reflection on the "material constitution" synthesize - with its emphasis on principles, values and fundamental orientations - what will be one of the most significant innovations of post-war constitutionalism, as it would highlight what Ferrara called "the essence of the Constitution" 34 . That is to say, the normativisation of a fundamental political principle through which the Constitution itself introduces the latter into the "concreteness of a legal system" 35 , which is the only sphere within which it can affect the surrounding social reality and, in this way, be fully realised. In short, by establishing a privileged link between the Constitution and fundamental political principles, between legality and politics, it is possible to profitably overcome the opposition between Kelsen's logic, which establishes a logical-formal primacy, and Schmittian logic, which attributes this primacy instead to a pure political principle.

\section{Democratic constitutionalism and property: between relativisation and functionalisation}

The third of the distinctive features of democratic and social constitutionalism is what has been

defined by Massimo Luciani as the "constitutional capture of the economic" 36 , based on the profound work of a social functionalisation of private property.

In fact, considering the new vision of the individual and his relations with society, the role of the State, now aimed at the development of the individual and his personality, changes in the attempt to ensure "effectuality" and universal usability to those fundamental rights previously only affirmed and declaimed $^{37}$. This objective evidently calls into question not only the relationship between the State and economy, but also the attitude that the former and, more generally, the political dimension hold towards

33 FIORAVANTI, M., Stato e costituzione. Materiali per una storia delle dottrine costituzionali, Giappichelli, Roma, 1993, p. 233.

34 FERRARA, G., La Costituzione. Dal pensiero politico alla norma giuridica, Feltrinelli, Milano, 2006, p. 242.

35 Ibid.

36 LUCIANI, M., “L'antrisovrano e la crisi delle costituzioni”, Rivista di diritto costituzionale, 1996, n. 1.

37 GAMBINO, S., "Dai diritti naturali ai diritti sociali. Un approccio storico-costituzionale nella prospettiva comparatistica", Diritto pubblico comparato ed europeo, 2002, p. 110.

CEFD Número 43 (2020) I ISSN: 1138-9877 I https://doi.org/10.7203/CEFD.43.17793 
property. Without ever questioning its existence, the latter is powerfully relativised and desacralised, that is, recognizing the links that bind property to society (and not simply to the individual who owns it) and providing not only the expropriation of the former for purposes of public utility. Nevertheless, more generally, it provides the functionalization of property to society and to those interests of society that do not coincide with the search for individual profit and the need for the accumulation of property itself.

Other scholars have spoken of a "constitutionalism of the social"38: a meaningful and significant expression, not only because it qualifies with an adjective ("social") the nature and new configuration of constitutionalism, but also because it specifies the unprecedented sphere. This sphere, the "social" within which the activity of limitation and containment of the power proper to constitutionalism is to operate and unfold and within which the same "conceptual framework that identifies constitutionalism"39 operates. What emerges from this process is a movement tending towards overcoming the separation between State and society, between public and private - which, as we have seen, had clearly distinguished 18th and 19th century liberalism. As a result of this separation, the only dimension within which the activity of division, limitation and containment of power knew an effective translation and application, was that of politics and the State apparatus. An application, the latter, which ended up ignoring those imbalances and concentrations of power existing in society and giving rise to forms of despotism different from political despotism, but equally hateful and damaging to human freedom. Those forms of "economic despotism" linked to the overwhelming power long held in factories, workshops and more generally in the places of production by employers and the entrepreneurial bourgeoisie. And this happened because liberal thought would have "renounced to examine also what power is created and implemented"40 by the employment contract and the situation of economic and working subordination that it entails and determines.

Therefore, the rigid separation between State and society fallen away at a theoretical level. The constitutional principle of the limitation of power unfolds its action among those social and economic relations that had been naturalized until then by liberal theory and for this reason considered eternal and inviolable. Its aim became not only the "conformation of the subject-State", but also the one related to

38 HERRERA, C. M., “La pensée constitutionnelle du social”, Droits, 2008, n. 2.

39 FERRARA, G., La Costituzione, cit., pp. 249-251.

40 SINZHEIMER, H., "La democratizzazione del rapporto di lavoro”, cit, p. 55. 
the "class relations"41. Democratic constitutionalism therefore takes on a new and different attitude regarding economic power by affirming and directing "its own normative ambition" towards it as well. If economic power had in fact previously played the role of the "active subject of the constitutional transformation", starting from the watershed represented by Weimar it became the "object of rules and limits" set by the constitutional orders, overturning "the relations between State and civil society". Taking the principle of the Ergreifung - namely the "constitutional capture of power" - to its extreme consequences, it is established that "none of its forms can logically" escape this capture, thus including in its perimeter and sphere of influence not only the Political, but also the Economic ${ }^{42}$. In virtue of this dynamic, the opinion that the Welfare State is nothing more than the main product of a democratic ideal conducted to its extreme consequences, that is, within the framework of a process of "politicisation of all issues" and of all social spheres, seems correct ${ }^{43}$. The result that is achieved in this way is that of taking economic activity away from the privatism into which liberal doctrine had relegated it. Recognizing the sociality and the importance of economic activity happened with respect to the living conditions of the many and to the exercise of political sovereignty by the citizens (but above all the citizen-workers) and to the formation of those decision-making processes that are the most direct consequence and form of expression of sovereignty.

Although they remain, private property and other fundamental rights inherited from the liberal constitutionalist tradition and more closely linked to proprietary individualism see their "legal structure" change - to take up the expression used by Franz Neumann ${ }^{44}$. Furthermore, there is an addition to the hierarchy implicit in the general catalogues of rights that had seen them in a prominent position until then. A hierarchy, this one just mentioned, which changes in such a way as to settle the rights of liberalbourgeois emanation within a situation of "(relatively) peaceful coexistence" with the new social rights promoted by the workers' and popular movements. The same economic freedoms connected to the institution of property, in the new constitutional context, cease to be purely negative freedoms. Thus, they assumed a "new configuration": they no longer appear as mere "guarantees of a right due to the

41 FERRARA, G., La Costituzione, cit., p. 249.

42 LUCIANI, M., “L’antisovrano e la crisi delle costituzioni”, cit., pp. 160-161.

43 PRETEROSSI, G., Ciò che resta della democrazia, Laterza, Bari, 2015, p. 26.

44 NEUMANN, F. L, "Libertà di coalizione e costituzione. La posizione dei sindacati nel sistema costituzionale", en Id., Il diritto del lavoro fra democrazia e dittatura, Il Mulino, Bologna, 1983, p. 155. 
individual" and make them, on the contrary, much more attentive to the various social interdependencies ${ }^{45}$. The attempt made is evidently that of "taming the terrible right" and of "introducing it into the world of juridical civilization" 46 . In the framework of an oxymoric "socialization of private law" imposed by the "dynamic balance" between conflicting social interests, property ends up losing the "executive function" held up to that moment, thus being bent to logics that do not necessarily coincide with market dynamics. It is a socialization which does not in any way affect the "principle of private autonomy", nor re-propose the "re-edition of ascribed statuses" linked to the class, but which operates instead in the sense of a disengagement of this autonomy from the area of influence of possessive individualism, thus highlighting the hitherto hidden "sociality of the individual condition"47.

\section{New constitutionalism and substantial equality: what type of relationship?}

It is evident that the novelty of democratic and social constitutionalism also lies in the way it relates to the question of equality, understood more and more in a substantial sense. The new constitutionalism, unlike liberal and nineteenth-century constitutionalism, actively intervenes on property because it recognizes the existence of a disproportion inherent in the social power of different individuals, which constitutes a relevant vulnus of the principle of equality, especially the rights related to participation in political life. In the constitutionalist "second wave" the "link between constitutionalism and equality" assumes a more solid foundation than its liberal past based on the recognition of the multiplicity of dimensions (including economic and social dimensions) within which the asymmetrical relationship between the different subjects can express itself $f^{48}$. What is in focus is the potentially explosive contradiction existing between a purely competitive capitalist market, on one hand, which is the bearer of a hierarchical, exclusive and authoritarian logic; and, on the other hand, the nascent mass democracies - then social and constitutional, typical of "multi-class States"49 (Giannini)-, were instead characterised, as far as their mechanisms of legitimation and formation of the collective will are concerned, by an ascending, egalitarian and participatory logic. A contradiction that was - more than

45 DE VERGOTTINI, G., Diritto costituzionale comparato, Cedam, Padova, 2013, p. 365.

46 FERRARA, G., "I diritti del lavoro e la costituzione economica in Italia e in Europa”, en Costituzionalismo.it, 2005 , n. 3, p. 4.

47 PROSPERO, M., "Il costituzionalismo e il lavoro", en Democrazia e diritto, 2008, n. 2, pp. 135-138.

48 GIORGI, C., “Le sinistre e il nuovo assetto costituzionale. Il progetto dell'eguaglianza”, en BERNARDINI, G., CAU, M., D’OTTAVIO, G., NUBOLA, C., (eds), L'età costituente. Italia 1945-1948, Il Mulino,Bologna, 2017, p. 386.

49 GIANNINI, M. S., Il pubblico potere. Stato e amministrazioni pubbliche, Il Mulino, Bologna, 1986, pp. 56-60. 
resolved - managed or, even better, governed effectively and profitably through interventionist and regulatory policies that will mark the Welfarist "social compromises" of the thirty or forty years in which it is possible to speak of an embedded liberalism.

The attention to the question of substantial equality permeates and crosses the whole of the Constitutions - both written and "material" - of the post-war period. But it is the Italian Constitutional Charter that values and confronts it more and better than other experiences. Among the best products of the collaboration between Christian-social doctrine and Marxist thought, the second paragraph of art. 3 succeeds in synthesizing in the best way possible, positivising and legally crystallizing it. The criticism of the liberal figure of the abstract individual who, with different forms and from different angles, both intellectual traditions had carried forward, placing at the center of the system a dynamic and tendential objective: the "full development of the human person" and the "removal" of material obstacles that prevent citizens and workers from "effective participation in the political, economic and social organization of the country". An objective which, by virtue of its programmatic nature, is called upon to inform not only government policies and the future activity of legislators, but the very interpretation of the other norms that make up the Charter, which must be read in accordance with it (as well as the labour principle set out at the beginning).

Thus qualifying the Italian one as a constitution-program, art. 3 incorporates into the constitutional system an "antagonistic contradiction"50, which prevents the Charter from being understood as a mere positivisation of a system of economic and social relations. While, on the contrary, this makes it a project for the transformation of those relations, which are still judged incongruous and incompatible with the political principle that has been transformed into a legal norm. As Calamandrei said - who, again for this reason, defined the post-war constitutions as "polemical" documents" ${ }^{51}$ - not a "point of arrival", but rather the "starting point of a revolution that is on its way"52. A transformative charge made possible by its articulation into "general clauses, capable of legitimizing a permanent action of political and social renewal, open to the possibility of continuous reinterpretation" of the dynamics of

50 GIORGI, C., "Le sinistre e il nuovo assetto costituzionale”, cit., p. 377.

51 CANFORA, L., La democrazia. Storia di un ’ideologia, Laterza, Bari, 2008, p. 263.

52 CALAMANDREI, P., "L'avvenire dei diritti di libertà”, in Id, Opere giuridiche, Morano, Napoli, 1968, vol. 3, p. 202. 
social domination and the apparatus within which they are structured ${ }^{53}$. Mortati considered the identification and recognition of the irremediable disagreement between social and material reality, on the one hand, and the "general principle of organization, on the other hand, at the basis of the new State", the "deepest essence" of the Charter and its main distinctive element ${ }^{54}$. There is an article that rejects the "restrictive, conservative and repressive" function of the law established up to that moment, and that instead adopts an innovative conception of the same, that is, aimed at enhancing its potential "promotional, redistributive, but also performative" function"55.

It is interesting, in this sense, to compare the Italian case with its Swedish constitutional equivalent, i.e. the second article of Chapter I of the Regeringsform, the main among the documents that make up the Swedish fundamental law, reformed in 1976. Article 2 in fact, echoing the Italian wording, States that the "personal, economic and cultural well-being" of the individual constitutes the "fundamental aim of public action", entrusting the "community" with the task of ensuring respect for social rights ("work", "housing", "education", "social care", "security", a "good living environment") 56. In short, a "positive" and constructivist conception of rights and freedom is outlined, which serves the Social Democrats - at the time, a majority party and at the height of their strength - as the constitutional basis for their activity of gradual but incisive reform of capitalism. However, at the end of the forty-year cycle of social-democratic hegemony, this article, whose contents largely coincide with Italian art. 3, does not have the programmatic and planning nature of a "promised revolution", all aimed at the future, as in the Italian case. It does not serve to legitimize ex ante an action of reform aimed at unhinging unfair and archaic social structures, but rather to sanction and constitutionally crystallize, ex post, the social achievements of a long period of time during which the goal had been achieving equality between capital and labour.

53 GALGANO, F., Le istituzioni dell'economia di transizione, Editori riuniti, Roma, 1978, p. 28.

54 MORTATI, C., "Il lavoro nella Costituzione”, Diritto del lavoro, 1954, n. 28, p. 153.

55 GIORGI, C., Le sinistre e il nuovo assetto costituzionale, cit. pp. 373-377

56 BORIONI, P., “I diritti sociali nella Costituzione svedese”, Annali della Fondazione Di Vittorio, 2007, p. 163. 


\section{The labour's role in the democratic constitutionalism: between social subject, fundamental right} and juridical science

"Concrete person", substantial equality, relativisation and functionalisation of property: all these elements and distinctive traits show how democratic and social constitutionalism stands out for the absolutely new attitude it takes towards "labour". As Antonio Cantaro stated:

Just as liberal constitutionalism and the dogmatics of the liberal rule of law had placed property and individual freedom as the undisputed center of their "discourse", thus, social constitutionalism and the dogmatics of the Welfare State had placed labour and individual well-being as the undisputed center of their "discourse". 57

In the framework of the new political and legal systems, the role played by work and labour is fundamental, both in terms of the space and value it occupies within the more general anthropological vision, and in terms of the attitude of law and the legal sciences towards it. The above-mentioned passage from the abstract and selfish idea of the individual to that, tangible and social, of the"person", became concrete. It became concrete thanks to the progressive emergence and emancipation of labour law - an emergence that proceeds in parallel with the broader process of the "constitutionalisation" of labour, understood as the "registration of the centrality that the working class comes to assume in the material structures of power on which capitalist society rests"58 - as an autonomous branch of law, and not a simple subset of private law. This was made possible by the anthropological conception, attentive to the dialectic between (juridical) equality and (social) difference, that was constitutive of labor law doctrine itself. The dialectic, "between the unitary, and original, subject of rights, and its subsequent, and conflictual, duality consumed along the lines of the opposition between labor and property" ${ }^{\prime 59}$. If, in fact, the liberal conception of the "free contract of employment" ignored (or pretended to ignore) the connection existing between the man called to perform the work and the work itself. Thus, the labour is commodified on the basis of an "abstract equation of equal goods and money", and consequently no

57 CANTARO, A., "La costituzionalizzazione del lavoro. Il secolo lungo", en CASADIO, G., (eds), I diritti sociali e del lavoro nella Costituzione italiana, Ediesse, 2006, p. 63.

58 For this concept, MEZZADRA, S., "Hugo Sinzheimer e il progetto weimariano di democrazia economica", Quaderni di azione sociale, 1994, n. 2. See also, CANTARO, A., "La costituzionalizzazione del lavoro", cit.; PROSPERO, M., "Il costituzionalismo e il lavoro", cit.

59 COSTA, P., “Cittadinanza sociale e diritto del lavoro nell'Italia repubblicana”, en Lavoro e diritto, 2009, n. 1, p. 39. 
attention is paid to the possible "destruction of the [...] personal labour force" (and with it, of his own person) of the worker ${ }^{60}$. The paradigm that is delineated through the affirmation of labour law rejects the jus-privatistic view of the attention to the protection of the "obligations" that are a responsibility of both parties (employee and employer). It therefore takes as its central and indispensable objective the protection of work performance, but above all "the human dimension in which it is carried out" ${ }^{61}$. Labour law not only immerse itself in the materiality of social relations by taking note of the "differences in social power" with respect to which the previous legal formalism had turned its head, but it also relates to the institution of the employment contract by drawing a "borderline in the exercise of this [owner's, employer's] social power"62. While not going so far as to question the "nature" itself of "private subordination", and limiting itself only to affecting its extent ${ }^{63}$, labour law, however, introduces into the system "a second element of conditioning", the "being a human person" that characterizes the worker. The attribute of the "personality" enters therefore

in the space left free from the restriction of ownership by presenting itself as a new, autonomous principle of law, which is intimately opposed to the old legal principle of ownership. Whereas before property was the only determining force in the conformation of the relationship between work and property, today we are faced with two opposing forces whose action will depend on the further development of that relationship. ${ }^{64}$

On one hand, the liberal ideology of the "free contract of employment", linked to the individual dimension of the bargaining between employer and service provider, gives rise to a "constitutionalisation of labour" in a purely objective sense, such as to consider labour a mere object, reducing it to the mere performance regulated by the contract. On the other hand, a constitutionalisation in a subjective sense is produced by the rise of the 20 th century social and mass democracies ${ }^{65}$. Starting from this type of constitutionalisation, it is possible to recognise the labour and workers as an authentic political and social

60 SINZHEIMER, H., “La democratizzazione del rapporto di lavoro”, cit., pp. 57-58.

61 Ivi, p. 58.

62 Ivi, p. 57.

63 Ivi, p. 68.

64 Ivi, p. 66.

65 CANTARO, A., "La costituzionalizzazione del lavoro”, cit., pp. 49-58.

CEFD Número 43 (2020) I ISSN: 1138-9877 I https://doi.org/10.7203/CEFD.43.17793 
subjectivity. Thus, this goes beyond the paternalistic approach of the social laws of late 19th century liberalism, which admits the existence of a social and workers' question, but which is oriented towards a mere negative integration of the workers' movement. Sinzheimer wrote, in an essay dedicated to reconstructing the trajectory of the relationship between work, law and democracy, that the worker, "who before was only an object, has been elevated to a juridical subject, arriving finally through the right to work to be considered a human person"66. This process of "constitutionalisation of work" is an example of the ways in which the subject at the basis of the constitutional order - a subject that cannot be reduced to the liberal homo singulus and that is already positioned beyond it - succeeds in assimilating the Romanesque category of the civis, connected to the functioning of representative bodies, but also the socius, which "demands a juridical form that is attentive to the social difference with respect to possessions" 67 .

It is now clearer the link that - by virtue of this de-formalisation of the subject - is now being established between the highly innovative category of the person and the labour principle that will engender and shape democratic-social constitutions, especially the Italian one. Within the new constitutional models, labour takes on a very peculiar and central function. This is an authentic medium between the "person" and "rights", as well as between the "person" and his or her fellow human beings: a "point of equilibrium", in short, "between subjectivity and sociality"68. It becomes the instrument to overcome the limits both of liberal atomism and formalism (with its abstract individual), and of the totalitarian organicism proper to fascism. Totalitarian organicism recognises labour, sometimes even celebrating it, but at the same time integrating it in a subordinate position within a hierarchical and authoritarian scheme, which categorically excludes any connection between labour and political and social rights, denying the idea of an autonomy of the social subject of labour ${ }^{69}$. The centrality that the Italian Constitution assigns to labour by taking it as a foundation, establishing a very strong link between it, democracy and the republican form, therefore represents at best the revolutionary nature of the Italian constitutional model compared to the Constitutional Charters of the previous season. The centrality that

66 SINZHEIMER, H., “La democratizzazione del rapporto di lavoro”, cit., p. 65.

67 PROSPERO, M., "Il costituzionalismo e il lavoro”, cit., p. 134.

68 COSTA, P., “Cittadinanza sociale e diritto del lavoro nell'Italia repubblicana”, cit., p. 43

69 Ivi, p. 41

CEFD Número 43 (2020) I ISSN: 1138-9877 I https://doi.org/10.7203/CEFD.43.17793 
the Italian Constitution assigns to labour by taking it as a foundation, makes a strong bond between it, democracy and the republican form. Hence, this represents the revolutionary nature of the Italian constitutional model compared to the Charters of the previous season. The reference to the dimension of labour, as an activity that - unlike property - unites the overwhelming majority of the people, "the human condition [...] more extensive [...] and more significant in terms of values", makes it possible to break with the liberal scheme. The latter, from Locke to Kant, considers the subordinate worker as a "man in a larval State", incompatible with full citizenship and the exercise of political rights, and on the contrary to convey an idea of labour as "the most effective affirmation of the social personality of man" and "the necessary means to satisfy his debt to society"70. Moreover, the reference to the labour finally makes it possible to substantiate the subject and to define a "concrete man", the homme situé, that is, not taken abstractly, but placed in the production process. A specification, this one related to the place occupied within the productive process, aimed not so much at delineating a differentiated system of rights but rather, on the one hand, at conveying an idea of sovereign people - and, consequently, of democracy wider and more extensive than the traditional one. On the other hand, it serves to identify, underlining them, those conditions and those social relations to be modified and transformed as potential obstacles to the full exercise of sovereignty and the set of rights that are reconnected to it - as in Art. 3, para. $2^{71}$. The Italian constitutional construction attempts to make the rights proclaimed factualthrough the labour principle, in order to ensure their effectiveness and universal usability that we have said to be an eminent characteristic of 20th century constitutionalism. In short, labour is considered by the constituents as the only real "foundation of an inclusive citizenship"72. This norm could be considered as programmatic, since it aims to make the profound meaning of the constitutional project explicit. The second paragraph of art. 3 - which can be considered an immediate specification of it. The labour principle, however, must be read and interpreted in connection with it - art. 1 represents the beating heart of the Charter, "a fundamental element of the political ideology [...] guiding the type of regime", and a general criterion

70 MORTATI, C, “Il lavoro nella Costituzione”, cit., p. 152.

71 Ivi, p. 153.

72 PROSPERO, M., "Il costituzionalismo e il lavoro", cit., p. 137.

CEFD Número 43 (2020) I ISSN: 1138-9877 I https://doi.org/10.7203/CEFD.43.17793 
called upon to shape and characterize "the type of State to be created" and the forms in which it is $\operatorname{articulated}^{73}$.

7. "Labour principle" and forms of sovereignty in the democratic constitutions: an excursus on the Italian case

Considering the labour principle related to the concept of popular sovereignty expressed in the same article, to the dynamic principle of substantial equality sculpted in art. 3 , to the functionalisation of private economic activity for general purposes (art. 41) and to the participation and collaboration of workers in the management of companies Stated in art. 46, it outlines the project of economic and social democracy that profoundly differentiates the Italian Constitution from its predecessors and narrower liberal democracies ${ }^{74}$. Narrower both from the point of view of the perimeter of the electoral body and from that of the spheres and area of influence over which the sovereignty of the people (worker) assumed as the foundation. In the affirmation, made above, that the activity of limiting the power proper to constitutionalism is now being extended from the political to the economic dimension, it is implicit not only the idea of a tendential reunification between politics and economy (the division of which is one of the main traits of liberal political forms). Furthermore, there is a redefinition of popular sovereignty and how it is exercised by the "people", and of the relationship between it and the forms of political representation.

In the opinion of a jurist such as Galgano, the above combined arrangement no longer makes it possible to speak, in the case of the model of democracy prefigured by the Italian Constitution, of a simple "citizens' democracy", in which "workers are also allowed to benefit, but only by extension of the political rights of the bourgeoisie". It is a model in which more "bridges" are built in order to reconnect and integrate the liberal democracy of the citizens with the new forms of "producer democracy", without however relegating them to the narrow space of civil society, but on the contrary uniting them and bringing them back - according to a circular and global logic - to political society and to the State. What is affirmed is thus "a right of political participation [which] is, for the first time in the history of Western

73 MORTATI, C., "Il lavoro nella Costituzione”, cit., p. 153

74 URBINATI, N., Costituzione italiana: articolo 1, Carocci, Roma, 2017.

CEFD Número 43 (2020) I ISSN: 1138-9877 I https://doi.org/10.7203/CEFD.43.17793 
constitutions, directly linked to the position that the individual occupies in the production process"75. It is in this sense, and in virtue of this connection, that it is possible to speak of a wider and more extensive conception of the sovereign people than the traditional one. The latter is not referable only to the "electoral body", it does not coincide perfectly with it because it is in fact something wider (and political rights, moreover, go well beyond electoral law and the audience to which the latter speaks ${ }^{76}$ ), which performs its sovereign functions not only through representative and parliamentary channels, but through a much more complex interweaving of delegated and direct forms of democracy ${ }^{77}$.

The workers participate both in the "political organization" of the country, and in its "economic and social organization" not only through the referendums, or organs of regional and territorial decentralization of the State - which for Galgano place representative democracy "on an inclined plane, [...] towards direct democracy", but also through collaboration in the management of companies provided for in art. 46, economic cooperation recognized in art. 45, and trade union freedom sanctioned in art. 39. The latter, in particular, can be considered as one of those forms that reconnect - if the trade union does not close its doors to corporate and aziendalistic logics - workers to the great issues of national politics. It is not by chance that sentence 290/74 of the Constitutional Court recognised the legitimacy of the recourse to "political strike" (which in Galgano's interpretation assumes "the function of referendum"78) as one of the possible instruments of implementation of the principle of participation Stated at Article 3, paragraph 2.

Trade union freedom therefore assumes, in the Italian constitutional system, an eminently political meaning, contributing to define and specify the "content" and the "structural articulations of popular sovereignty". And this happens since the particular meaning and value with which all the economic freedoms illustrated in the Charter are presented, such that they are not exhausted "in the purely economic sphere" and that they escape from a purely negative dimension, but, on the contrary,

75 GALGANO, F., Le istituzioni dell'economia di transizione, cit., p. 46.

76 CRISAFULLI, V., "La sovranità popolare nella Costituzione italiana (note preliminari)", en Id., Stato, popolo, governo. Illusioni e delusioni costituenti, Giuffré, Milano, 1985, pp. 114-115.

77 GALGANO, F., Le istituzioni dell'economia di transizione, cit.; CRISAFULLI, V., "La sovranità popolare nella Costituzione”, cit., p. 144

78 GALGANO, F., Le istituzioni dell'economia di transizione, cit., p. 53. 
"functionally connecting [...] to the same political freedoms" and thus assuming a positive connotation, connected to the determination of national political life by the citizens ${ }^{79}$.

The founding of the Italian Republic on the labour principle has therefore an effective impact on the same way of conceiving and interpreting the principle of popular sovereignty, marking a profound discontinuity with the previous doctrines of sovereignty and with the Charters or statutes within which they had been Stated ${ }^{80}$. A discontinuity with the model of the nineteenth-century Rechtsstaat, which with its doctrine of State sovereignty assimilates and incorporates the people within the State - is the only place in which the former can find "its true expression as legal unity" -, denying it, given the octroyée nature of the Charters of the time, any constituent function and legitimizing of the State ${ }^{81}$. Besides, the experiences of representative States accept the principle of popular sovereignty, considering, however, the "people" a simple source, the place that emanates and from which emerges a sovereignty fatally destined to be, so to speak, alienated in favour of the State-apparate as regards its concrete exercise ${ }^{82}$. That is, recognizing the "people" the ownership of sovereignty, but not also the exercise of this sovereignty: a constituent power, in short, which has feeble relations with the constituted power, with respect to whose action it is a simple object and passive recipient.

On the contrary, the Italian Constitution, with the definition contained in the second paragraph of art. 1, would adopt a concept of popular sovereignty to innovate in depth the "relations between the Statesubject and the people" 83 . The identity between the two terms is not resolved, however, in the subordinate integration of the people into the State, but, on the contrary, in the assumption by the latter of an instrumental character with respect to the first. The second paragraph of art. 1, affirming that "sovereignty belongs to the people", and that the latter is called to exercise it within the limits and forms dictated by the rest of the constitutional text, calls into question both ownership and the exercise of this sovereignty. Thus it does not limit itself to identify the place or element from which the order originates, but it

\section{Ibid}

80 On the relationship between the concept of "people" and the one of "sovereignty", see OLIVIERI, A. F., "Sovranità popolare e democrazia sociale in Lelio Basso", en GAMBILONGHI, M., TEDDE, A., Progettare l'uguaglianza, cit. For a more general overview of the topic, see also GALLI, C., Sovranità, Il Mulino, Bologna, 2019.

81 CRISAFULLI, V., “La sovranità popolare nella Costituzione”, cit.,, pp. 95-96.

82 Ivi, pp. 137-138.

83 Ivi, p. 105.

CEFD Número 43 (2020) I ISSN: 1138-9877 I https://doi.org/10.7203/CEFD.43.17793 
identifies the subject of the "supreme power of government"84. The objective of art. 1 is therefore to affirm not so much a "generic fundamental consensus" of citizens towards the new State, but rather their effective capacity to participate in the formation of the "supreme ruling will" 85 . The emphasis given by the constituents to the notion that sovereignty belongs to the people, instead of a simple emanation from it, refers to a conception of democracy and the exercise of sovereignty that is broader than the traditionally liberal one, which is achieved through a plurality of channels and dimensions that cannot be reduced to the simply electoral and representative one.

It is no coincidence that the attribution of sovereignty only to the subject-State, which implies a full identification between State and "people", and a passive assimilation of the latter into the former, ends up, historically, in the primacy held by the executives over the elected assemblies, since the "State then ends up [...] to mean the Government (in the strict sense)" ${ }^{86}$. Therefore, the representative and parliamentary States, upright and imbued with the ideology of State sovereignty, have a prevalence of the executive over the political system. The representative States that assume instead popular sovereignty as ordering principle assign centrality and primacy to the legislative and to the elected assemblies, thus they characterise themselves as parteienStaat, or "State of the parties". The sovereignty of the people and the concept of sovereign people take on an expansive meaning and it does not translate, therefore, into a mythical - and libertarian traits - sovereignty of the citizen taken individually and atomistically, but, if anything, into the new centrality conquered by the intermediate bodies, unions and mass parties, an authentic link between State and society. Due to the fact that parties are an expression of the "democracy that organizes itself" (Togliatti), a direct democracy is realised in the framework of the dynamics generated by them: however, it is something different from the "directism", based on the isolated individual and constantly threatened by particularistic and corporative drifts. In the Italian constitutional context, for example, according to art. 49, intermediate bodies are no longer treated according to the merely guarantor approach proper to the liberal tradition. The art. 1, if reread in function of art. 49, assumes a new and different valence: the sovereignty of the citizen is no longer declined in an individualistic perspective, but in a social and cooperative sense, by combining the sovereignty $u t i$

84 Ivi, p. 108.

85 Ivi, p. 111.

86 Ivi, p. 135.

CEFD Número 43 (2020) I ISSN: 1138-9877 I https://doi.org/10.7203/CEFD.43.17793 
singulus, which considers it as a member of the electoral body, with a sovereignty uti socius, which inserts it in the associative dynamic proper to the political party (or trade union) ${ }^{87}$.

Vezio Crisafulli claimed that the new concept of popular sovereignty is related to the shift of the meaning of "State": a term which, from being limited as it was only to the apparatus that governs and administers, knows an extension, as far as including "the entire politically organized community, in its dialectical unity of rulers and governed". What emerges is the passage from the State-government (or State-apparatus) characterizing the Rechtsstaat, to the State-society proper to twentieth-century democratic-social constitutionalism ${ }^{88}$. The slippage explains the above mentioned process of "permeation between people and State" and the "motion on the Republican State" drafted by Massimo Severo Giannini that represents "the intimate structure of democracy"89.

87 GALGANO, F., Le istituzioni dell'economia di transizione, cit., p. 56.

88 CRISAFULLI, V., “La sovranità popolare nella Costituzione”, cit.,, pp. 98-101.

89 GIANNINI, M. S., "Mozione sullo Stato repubblicano", Bollettino di informazione e documentazione del Ministero per la Costituente, 1946, n. 12, ahora en Id., Per uno Stato democratico-repubblicano, Edizioni di Storia e Letteratura, Roma, 2016 , p. 51. 


\section{Bibliography}

BARCELLONA P., CANTARO, A., La sinistra e lo Stato sociale, Editori Riuniti, Roma 1984.

BARCELLONA, P., Stato e mercato, De Donato, Bari 1976.

BASSO, L., Il principe senza scettro. Democrazia e sovranità popolare nella Costituzione e nella realtà italiana, Feltrinelli, Milano, 1958.

BORIONI, P., "I diritti sociali nella Costituzione svedese”, Annali della Fondazione Di Vittorio, 2007.

CALAMANDREI, P., "L’avvenire dei diritti di libertà”, in Id, Opere giuridiche, Morano, Napoli, 1968, vol. 3.

CANFORA, L., La democrazia. Storia di un'ideologia, Laterza, Bari, 2008.

CANTARO, A., "La costituzionalizzazione del lavoro. Il secolo lungo", en CASADIO, G., (eds), I diritti sociali e del lavoro nella Costituzione italiana, Ediesse, 2006.

CONTI, F., SILEI, G. Breve storia dello Stato sociale, Carocci, Roma 2013.

COSTA, P., "Alle origini dei diritti sociali: «Arbeitender Staat e tradizione solidaristica»”, en GOZZI, G., (edS.), Democrazia, diritti, costituzione: i fondamenti costituzionali delle democrazie contemporanee, Il Mulino, Bologna, 1997.

COSTA, P., "Cittadinanza sociale e diritto del lavoro nell'Italia repubblicana”, en Lavoro e diritto, 2009, n. 1.

CRISAFULLI, V., "La sovranità popolare nella Costituzione italiana (note preliminari)", en Id., Stato, popolo, governo. Illusioni e delusioni costituzioni, Giuffré, Milano, 1985.

D’ALBERGO, S., "Dalla democrazia sociale alla democrazia costituzionale”, Costituzionalismo.it, 3/2005.

DE FELICE, F., "I tre volti del fascismo maturo", en MARRAMAO, G., TRONTI, M., VILLARI, L., DE FELICE, F., (eds) Stato e capitalismo negli anni Trenta, Editori riuniti, Roma, 1979.

DE FELICE, F., "La formazione del regime repubblicano", En GRAZIANO, L., TARROW, S., (eds) La crisi italiana, Einaudi, Torino, 1976.

DE FELICE, F., La storiografia delle élites nel secondo dopoguerra, in Italia contemporanea,1983, n. 153.

DE VERGOTTINI, G., Diritto costituzionale comparato, Cedam, Padova, 2013.

FERRARA, G., "I diritti del lavoro e la costituzione economica in Italia e in Europa", en Costituzionalismo.it, 2005, n. 3.

FERRARA, G., La Costituzione. Dal pensiero politico alla norma giuridica, Feltrinelli, Milano, 2006.

FIORAVANTI, M., “La crisi dello Stato liberale di diritto", Ars interpretandi. 2011,n. 1.

FIORAVANTI, M., "Le dottrine della costituzione in senso materiale", Historia constitucional, 2011, n. 12.

FIORAVANTI, M., Costituzione, Il Mulino, Bologna, 1999.

FIORAVANTI, M., Stato e costituzione. Materiali per una storia delle dottrine costituzionali, Giappichelli, Roma, 1993.

FORSTHOFF, E., Rechtsstaat im Wandel : Verfassungsrechtliche Abhandlungen 1950-1964, W. Kohlhammer, Stuttgart, 1964.

GALGANO, F., Le istituzioni dell'economia di transizione, Editori riuniti, Roma, 1978.

GALLI, C., Sovranità, Il Mulino, Bologna, 2019.

GAMBINO, S., "Dai diritti naturali ai diritti sociali. Un approccio storico-costituzionale nella prospettiva comparatistica", Diritto pubblico comparato ed europeo, 2002. 
GIANNINI, M. S., "Mozione sullo Stato repubblicano", Bollettino di informazione e documentazione del Ministero per la Costituente, 1946, n. 12, ahora en Id., Per uno Stato democratico-repubblicano, Edizioni di Storia e Letteratura, Roma, 2016.

GIANNINI, M. S., Il pubblico potere. Stato e amministrazioni pubbliche, Il Mulino, Bologna, 1986.

GIORGI, C., "Le sinistre e il nuovo assetto costituzionale. Il progetto dell'eguaglianza", en BERNARDINI, G., CAU, M., D’OTTAVIO, G., NUBOLA, C., (eds), L'età costituente. Italia 1945-1948, Il Mulino,Bologna, 2017.

GUERRIERI S., "I giuristi e la genesi dello Stato sociale in Francia: dalla Liberazione alla Costituzione del 1946", Quaderni fiorentini per la storia del pensiero giuridico, n. 46, tomo I, 2017..

HERRERA, C. M., "La pensée constitutionnelle du social”, Droits, 2008, n. 2.

LUCIANI, M., “L'antrisovrano e la crisi delle costituzioni”, Rivista di diritto costituzionale, 1996, n. 1.

MAIER, C. S., La rifondazione dell'Europa borghese, Il Mulino, Bologna, 1999

MARILLI, G. O., "Durkheim e l'ideologia repubblicana. Lo Stato fra individualismo e solidarismo", en GAMBILONGHI, M., TEDDE, A. (eds), Progettare l'uguaglianza. Momenti e percorsi della democrazia sociale, Mimesis, 2019.

MARRAMAO G., Dopo il Leviatano. Individuo e comunità, Bollati boringhieri, Torino, 1995.

MARQUARDT, LLINAS, PEREZ (eds.), Querétaro 1917 \& Weimar 1919: el centenario del

constitucionalismo de la democracia social, Grupo Editorial Ibáñez, Bogotá, 2019.

MEZZADRA, S., "Hugo Sinzheimer e il progetto weimariano di democrazia economica", Quaderni di azione sociale, 1994, n. 2.

MORTATI, C., "Costituzione, dottrina generale”, en Enciclopedia del diritto, XI, Giuffrè, Milano, 1962.

MORTATI, C., "Il lavoro nella Costituzione”, Diritto del lavoro, 1954, n. 28.

NEUMANN, F. L, "Libertà di coalizione e costituzione. La posizione dei sindacati nel sistema costituzionale", en Id., Il diritto del lavoro fra democrazia e dittatura, Il Mulino, Bologna, 1983.

OLIVIERI, A. F., "Sovranità popolare e democrazia sociale in Lelio Basso", en GAMBILONGHI, M., TEDDE, A., Progettare l'uguaglianza. Momenti e percorsi della democrazia sociale, Mimesis, Milano, 2019.

PRETEROSSI, G., Ciò che resta della democrazia, Laterza, Bari, 2015.

PROSPERO, M., "Il costituzionalismo e il lavoro", en Democrazia e diritto, 2008, n. 2.

RAPINI, A., Lo Stato sociale, Archetipolibri, Bologna, 2010;

RITTER G., Storia dello Stato sociale, Laterza, Bari, 1996.

RIVERO, J., VEDEL, G., "Les principes économiques et sociaux de la Constitution: le préambule”, Droit social, n. 31, 1947.

RUIPEREZ, A, El constitucionalismo democrático en los tiempos de la globalización: reflexiones rousseaunianas en defensa del estado constitucional democrático y social, Universidad Nacional Autónoma de México, México D. F., 2005

SCHEININ, M., (eds), Welfare state and constitutionalism: nordic perspectives, Nordic Council of Ministers, Copenaghen, 2001.

SINZHEIMER, H., "La democratizzazione del rapporto di lavoro", en VARDARO, G., ARRIGO, G.(eds), Laboratorio Weimar. Conflitti e diritto del lavoro nella Germania prenazista, Edizioni Lavoro, Roma, 1982.

CEFD Número 43 (2020) I ISSN: 1138-9877 I https://doi.org/10.7203/CEFD.43.17793 